\title{
Delivering cancer genetics services-new ways of working
}

\author{
Ros Eeles · Glyn Purland · Jane Maher · \\ D. Gareth Evans
}

Published online: 8 December 2007

(C) Springer Science+Business Media B.V. 2007

Erratum to: Familial Cancer (2007) 6(2): 163-167

DOI: 10.1007/s10689-007-9137-9

In Table 1, the percentage of high risk assessments for the North Kirklees pilot site should be $25 \%$, rather than $45 \%$.

The online version of the original article can be found under doi:10.1007/s10689-007-9137-9.

R. Eeles $(\square)$

Cancer Genetics Unit, Orchard House, The Institute of Cancer Research \& Royal Marsden NHS Foundation Trust,

Downs Road, Sutton, Surrey SM2 5PT, UK

e-mail: Rosalind.Eeles@icr.ac.uk

G. Purland · J. Maher

Macmillan Cancer Support, London, UK

J. Maher

Mount Vernon Cancer Centre, Northwood,

Middlesex HA6 2RN, UK

D. G. Evans

Academic Unit of Medical Genetics and Regional Genetics

Service, St Mary's Hospital (SM2), Hathersage Road,

Manchester M13 OJH, UK 